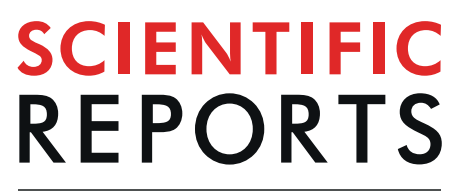

natureresearch

Received: 5 March 2018

Accepted: 21 August 2019

Published online: 03 September 2019

\section{Habitat divergence shapes the morphological diversity of larval insects: insights from scorpionflies}

\author{
Lu Jiang ${ }^{1,2}$, Yuan Hua ${ }^{1,3}$, Gui-Lin Hu ${ }^{1} \&$ Bao-Zhen Hua ${ }^{1}$
}

Insects are the most diverse group of organisms in the world, but how this diversity was achieved is still a disputable and unsatisfactorily resolved issue. In this paper, we investigated the correlations of habitat preferences and morphological traits in larval Panorpidae in the phylogenetic context to unravel the driving forces underlying the evolution of morphological traits. The results show that most anatomical features are shared by monophyletic groups and are synapomorphies. However, the phenotypes of body colorations are shared by paraphyletic assemblages, implying that they are adaptive characters. The larvae of Dicerapanorpa and Cerapanorpa are epedaphic and are darkish dorsally as camouflage, and possess well-developed locomotory appendages as adaptations likely to avoid potential predators. On the contrary, the larvae of Neopanorpa are euedaphic and are pale on their trunks, with shallow furrows, reduced antennae, shortened setae, flattened compound eyes on the head capsules, and short dorsal processes on the trunk. All these characters appear to be adaptations for the larvae to inhabit the soil. We suggest that habitat divergence has driven the morphological diversity between the epedaphic and euedaphic larvae, and may be partly responsible for the divergence of major clades within the Panorpidae.

Insects are the most diverse organisms on the earth, exhibiting the most diverse morphological features and occupying a wide range of ecological niches ${ }^{1,2}$. The driving forces leading to this diversity have long received great attention from evolutionary biologists. Some authors consider that the diversity is attributed to co-radiation with angiosperm plants, judged from evidence of herbivorous or pollinating insects ${ }^{3-7}$. Others argue that it is correlated with complicated sexual behaviors, focusing on the sexually mature adults ${ }^{8,9}$. With respect to the insects that neither feed on plants nor undergo sexual reproduction, however, the driving force of diversity is still disputable.

Larvae, the immature stage of holometabolous insects, represent a significant developmental stage in insects' life histor ${ }^{2}$, and are considered feeding devices that acquire nutrition for the development of pupal and imaginal stages ${ }^{10,11}$. On the other hand, larvae as a free-living life stage also have their own survival requirements and often exhibit dramatically diverse morphological features as well as biological characteristics ${ }^{12,13}$. This morphological diversity is not only distinct among distant groups, but also may be noticeable in closely related species ${ }^{14}$. However, the information on insect larvae is only available for about $2 \%$ of known holometabolous species ${ }^{15,16}$. Our knowledge of larvae is even more limited, fragmentary to be more specific, for the groups of less economic significance as in Mecoptera.

The larvae of Mecoptera exhibit a wide range of morphological diversity ${ }^{17-19}$, although Mecoptera, as a small order, are only composed of nine extant families with approximately 650 extant species in the world ${ }^{20-22}$. The larvae of Nannochoristidae are campodeiform and aquatic, living in the substrate of streams ${ }^{23-25}$. The larvae of Boreidae are scarabaeiform and herbivorous, creeping on or boring into live mosses ${ }^{26-28}$. In most other families of Pistillifera (including Apteropanorpidae, Choristidae, Bittacidae, Panorpodidae, and Panorpidae), the larvae are generally eruciform and edaphic, occurring in the soil or on the ground ${ }^{18,29,30}$ and exhibiting different feeding habits at the family level ${ }^{31}$.

\footnotetext{
${ }^{1}$ Key Laboratory of Plant Protection Resources and Pest Management, Ministry of Education, College of Plant Protection, Northwest A\&F University, Yangling, Shaanxi, 712100, China. ${ }^{2}$ Key Laboratory of Economic and Applied Entomology of Liaoning Province, College of Plant Protection, Shenyang Agricultural University, Shenyang, Liaoning, 110866, China. ${ }^{3}$ College of Life Sciences, Northwest A\&F University, Yangling, Shaanxi, 712100, China. Lu Jiang and Yuan Hua contributed equally. Correspondence and requests for materials should be addressed to B.-Z.H. (email: huabzh@nwafu.edu.cn)
} 


\begin{tabular}{|l|l|l|l|}
\hline Taxa & Localities & Dates & Collectors \\
\hline Dicerapanorpa magna (Chou in Chou et al., 1981$)$ & Tiantaishan $\left(34^{\circ} 13^{\prime} \mathrm{N}, 106^{\circ} 59^{\prime} \mathrm{E}\right)$ & vi. 2015 & Lu Jiang \\
\hline Dicerapanorpa sp. & Hualongshan $\left(32^{\circ} 01^{\prime} \mathrm{N}, 109^{\circ} 21^{\prime} \mathrm{E}\right)$ & vii. 2015 & $\mathrm{Lu} \mathrm{Jiang}$ \\
\hline Cerapanorpa nanwutaina (Chou in Chou et al., 1981$)$ & Tongtianhe $\left(34^{\circ} 11^{\prime} \mathrm{N}, 106^{\circ} 40^{\prime} \mathrm{E}\right)$ & vi. 2015 & $\mathrm{Lu} \mathrm{Jiang}$ \\
\hline C. dubia (Chou \& Wang in Chou et al., 1981$)$ & Tiantaishan $\left(34^{\circ} 13^{\prime} \mathrm{N}, 106^{\circ} 59^{\prime} \mathrm{E}\right)$ & vi. 2015 & $\mathrm{Lu} \mathrm{Jiang}$ \\
\hline Panorpa curva Carpenter, 1938 & Tongtianhe $\left(34^{\circ} 11^{\prime} \mathrm{N}, 106^{\circ} 40^{\prime} \mathrm{E}\right)$ & vi. 2015 & $\mathrm{Lu} \mathrm{Jiang}$ \\
\hline P. chengi Chou in Chou et al., 1981 & Huoditang $\left(33^{\circ} 26^{\prime} \mathrm{N}, 108^{\circ} 27^{\prime} \mathrm{E}\right)$ & viii. 2015 & Jie Lu \& Lu Liu \\
\hline Neopanorpa lipingensis Cai \& Hua, 2009 & Zhenping $\left(31^{\circ} 53^{\prime} \mathrm{N}, 109^{\circ} 31^{\prime} \mathrm{E}\right)$ & vii. 2015 & $\mathrm{Lu} \mathrm{Jiang}$ \\
\hline N. longiprocessa Hua \& Chou, 1997 & Huoditang $\left(33^{\circ} 26^{\prime} \mathrm{N}, 108^{\circ} 27^{\prime} \mathrm{E}\right)$ & vii. 2015 & Jie Lu \& Lu Liu \\
\hline
\end{tabular}

Table 1. Information of studied organisms and their localities in Shaanxi, China.

Panorpidae is the largest family in Mecoptera and comprises approximately 470 species currently assigned to eight genera, mainly confined to the Northern Hemisphere ${ }^{32-37}$. The eruciform larvae of Panorpidae inhabit the soil $^{38-43}$. Based on our recent investigations, the larvae of different panorpid species exhibit notable morphological differences on head capsules, thoracic legs, abdominal prolegs, spiracles, and chaetotaxy ${ }^{44-47}$. However, whether these morphological and biological differences reflect the evolutionary process or are just adaptations for habitats has not been clarified to date.

In this study, eight species in four genera of Panorpidae were investigated and compared for larval morphological traits and correlated habitat preferences. Both morphological and habitat features were marked on a molecular phylogenetic tree in order to understand further how this larval morphological diversity was achieved.

\section{Methods}

Insect collection and rearing. Live adults were captured with sweeping nets in Shaanxi Province, central China from early June to late August in 2015. Detailed collection information is listed in Table 1.

To rear the scorpionflies, loamy soil was collected from the Tiantaishan Forest Park in the Qinling Mountains, where adult scorpionflies were collected, as rearing substrate. The soil was kept in a sealed valve bag, sterilized in an autoclave at $85^{\circ} \mathrm{C}$ for $30 \mathrm{~min}$, left to cool for $3 \mathrm{~h}$, and then sprayed little water till the moisture reached approximately $15 \%(\mathrm{M} / \mathrm{M})$.

Adults were reared in pairs in plastic jars covered with gauze under natural conditions. The jars were filled with 4-5 cm moist loamy soil in depth. Both adults and larvae were daily provided chopped mealworms as food items ${ }^{48}$. Live fourth-instar larvae (within $5 \mathrm{~d}$ after molting) were used for behavioral experiments. Photographs were taken with a Nikon D90 digital camera (Nikon, Tokyo, Japan).

Morphological observations. For morphological observations, the larvae were fixed in Carnoy's solution for $12 \mathrm{~h}$ and preserved in $75 \%$ ethanol. The fixed larvae were dissected and dehydrated in a graded ethanol series, replaced by tertiary butanol, freeze-dried for $3 \mathrm{~h}$, sputter-coated with gold, and examined under a Hitachi $\mathrm{S}-3400 \mathrm{~N}$ scanning electron microscope (Hitachi, Tokyo, Japan) at $5 \mathrm{kV}$. Morphological graphpads were provided in the supplementary dataset 2.

Habitat preferences. To examine habitat preferences under laboratory conditions $\left((19 \pm 1){ }^{\circ} \mathrm{C}, 75 \% \pm 5 \%\right.$ relative humidity, $14 \mathrm{~L}: 10 \mathrm{D}$ photoperiod), fourth-instar larvae $(n=50)$ were placed on the soil surface $(7 \mathrm{~cm}$ in depth) in a plastic box $(25 \mathrm{~cm} \times 15 \mathrm{~cm} \times 15 \mathrm{~cm})$ at daytime. Numbers of larvae remained on the soil surface were recorded successively in the following three hours. For each species the experiment was replicated three times.

To investigate circadian rhythmicity, fourth-instar larvae $(n=50)$ were reared under the laboratory condition mentioned above. The numbers of larvae on the soil were recorded every two hours over a period of $24 \mathrm{~h}$. The experiment was replicated three times in three successive days for each species. Data analyses were carried out using R ver. 3.3.1 (R Development Core Team, Vienna, Austria). Original data of the behavior experiments were provided in the supplementary dataset 1 .

Molecular phylogenetic analyses. Two mitochondrial gene fragments (cytochrome $c$ oxidase subunits I and II, COI and COII) and one nuclear gene fragment (28S ribosomal RNA, $28 S$ rRNA) were used in the phylogenetic analyses. The DNA sequences of Dicerapanorpa sp. and Neopanorpa lipingensis were generated based on primers from previous studies ${ }^{49,50}$. Other DNA sequence data were obtained from a previous study ${ }^{33}$. Two species of Panorpodidae, Panorpodes kuandianensis and Brachypanorpa carolinensis, were used as outgroups.

DNA sequences were checked, assembled and edited with SeqMan ${ }^{51}$. Multiple sequence alignment was performed using ClustalX 2.0.21 with default parameters ${ }^{52}$. The gappy regions at the beginning and end of the alignment were manually deleted with BioEdit 7.0.9.0. $0^{53}$. The best partition schemes and models were estimated for the whole data matrix based on the program PartitionFinder v1.1.1 ${ }^{54}$ under Bayesian Information Criterion (BIC). The concatenated dataset was divided into four partitions, first codon position of COI and COII with $\operatorname{TrN}+\mathrm{I}$, second codon position of $C O I$ and $C O I I$ with $\mathrm{HKY}+\mathrm{I}$, third codon position of $C O I$ and $C O I I$ with $\mathrm{HKY}+\mathrm{G}$, and $28 S$ with $\mathrm{HKY}+\mathrm{G}$.

Ethics approval and consent to participate. No specific permits were required for the described field studies: a) no specific permissions were required for the locations/activities; b) locations were not privately owned or protected; and c) the field studies did not involve endangered or protected species. 

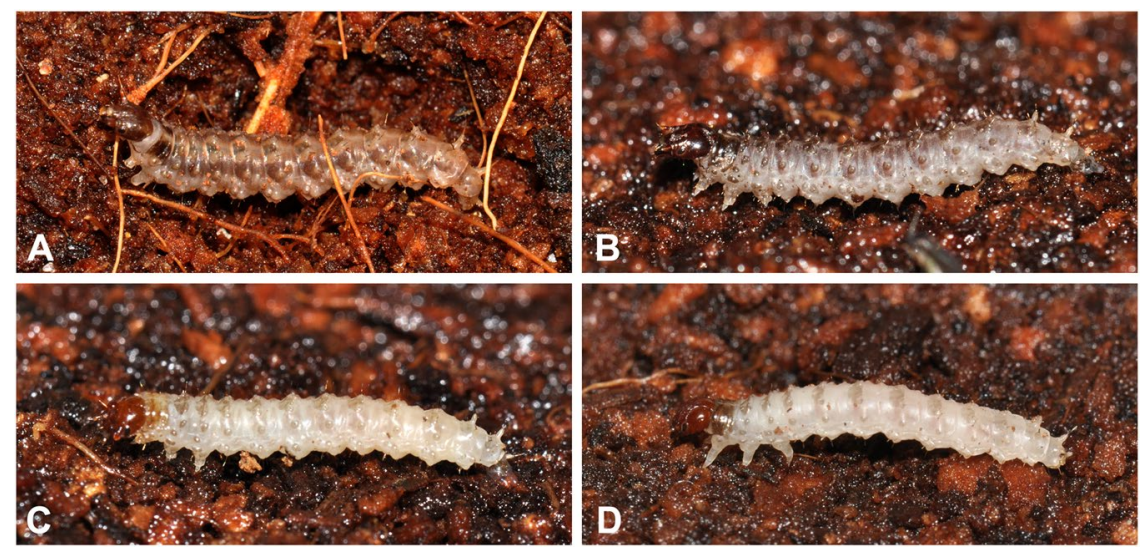

Figure 1. Larvae of Panorpidae in habitus. (A) Dicerapanorpa magna; (B) Cerapanorpa nanwutaina; (C) Panorpa curva; (D) Neopanorpa lipingensis.

\section{Results}

Morphological comparison. The larvae of all panorpid species are eruciform, possessing three pairs of thoracic legs and eight pairs of abdominal prolegs (Fig. 1). The larval heads are heavily sclerotized, bearing a pair of compound eyes, a pair of 3-segmented antennae, and the mandibulate mouthparts that are directed ventrally. The larval trunks are roughly cylindrical, equipped with paired erect subdorsal annulated processes on A1-A9 and a single mid-dorsal annulated process on A10. The paired dorsal processes on A1-A7 are much shorter than those on A8-A10. The body color varies dorsally among the genera.

The larvae of Dicerapanorpa are darkish brown dorsally and possess two dark broad subdorsal stripes (Fig. 1A). The larvae of Cerapanorpa are darkish grey dorsally, but dull pale ventrally (Fig. 1B). The larvae of Panorpa and Neopanorpa are grossly pale on the whole body, including dorsal and ventral surfaces (Fig. 1C,D).

The head capsules are furnished with 13 pairs of setae arranged symmetrically. The setae vary in length among the species and are much shorter in Neopanorpa than in other three genera (Fig. 2).

The head capsules are delimited by several normal sutures and sulci in all the species (Fig. 2A-C), but some distinct shallow furrows are present in the occipital, coronal and genal areas in Neopanorpa larvae (Fig. 2D).

The larval compound eyes are externally protuberant in Dicerapanorpa, Cerapanorpa, and Panorpa with clearly defined facets of ommatidia (Fig. 2A-C), but roughly flat in Neopanorpa with the facets of ommatidia indistinct (Fig. 2D).

The three-segmented antennae are slender and longer in Dicerapanorpa, Cerapanorpa, and Panorpa than in Neopanorpa (Fig. 2).

The thoracic legs are four-segmented, each consisting of a stout coxa, a cylindrical elongate femur, a slender tibia, and a short pointed hirsute tarsus. A remarkable triangular tibial lobe is present posteromesally on the tibiae of Dicerapanorpa, Cerapanorpa, and Panorpa (Fig. 3A-C), but absent in Neopanorpa (Fig. 3D).

Hirsute unsegmented ventral prolegs are present on the first eight abdominal segments. These prolegs are well developed in Dicerapanorpa, Cerapanorpa, and Panorpa (Fig. 3E-G), but remarkably reduced on the anterior four pairs in Neopanorpa (Fig. 3H).

The dorsal annulated processes are very similar between the species of each genus, but vary in length among the genera. These dorsal processes are very prominent in Dicerapanorpa, median-sized in Cerapanorpa, and relatively shorter in Panorpa and Neopanorpa (Fig. 3).

Habitat preference. Larval habitat preferences were very similar between the species of each genus, but varied significantly among the genera (Fig. 4).

In Dicerapanorpa more than 45 of 50 individuals stayed consistently on the soil (Fig. 4A,B), indicating that the larvae of Dicerapanorpa are epedaphic.

In Cerapanorpa the number of larvae on the soil decreased immediately, but then remained at around half number (Fig. 4C,D). This suggests that the larvae of Cerapanorpa are hemi-epedaphic, occurring either on the ground or shallowly in the soil.

In Panorpa over half individuals entered the soil within $1 \mathrm{~h}$ exposure to light, and almost all the larvae burrowed into the soil in $3 \mathrm{~h}$ (Fig. 4E,F), indicating that the larvae of Panorpa are euedaphic, preferring to inhabit the soil.

In Neopanorpa the larvae immediately burrowed into the soil and became completely invisible in $3 \mathrm{~h}$ (Fig. 4G,H), showing that the larvae of Neopanorpa are also euedaphic, inhabiting the soil most of their life time.

Circadian rhythms. The larval circadian rhythms also exhibited very similar patterns between the species of each genus, but were significantly different among the four genera (Fig. 5).

In Dicerapanorpa at any time of the day or night, the number of larvae on the soil amounted to at least 45 of 50 (Fig. 5A,B), indicating that the larvae of Dicerapanorpa exhibit no behavioral difference during the whole day. 

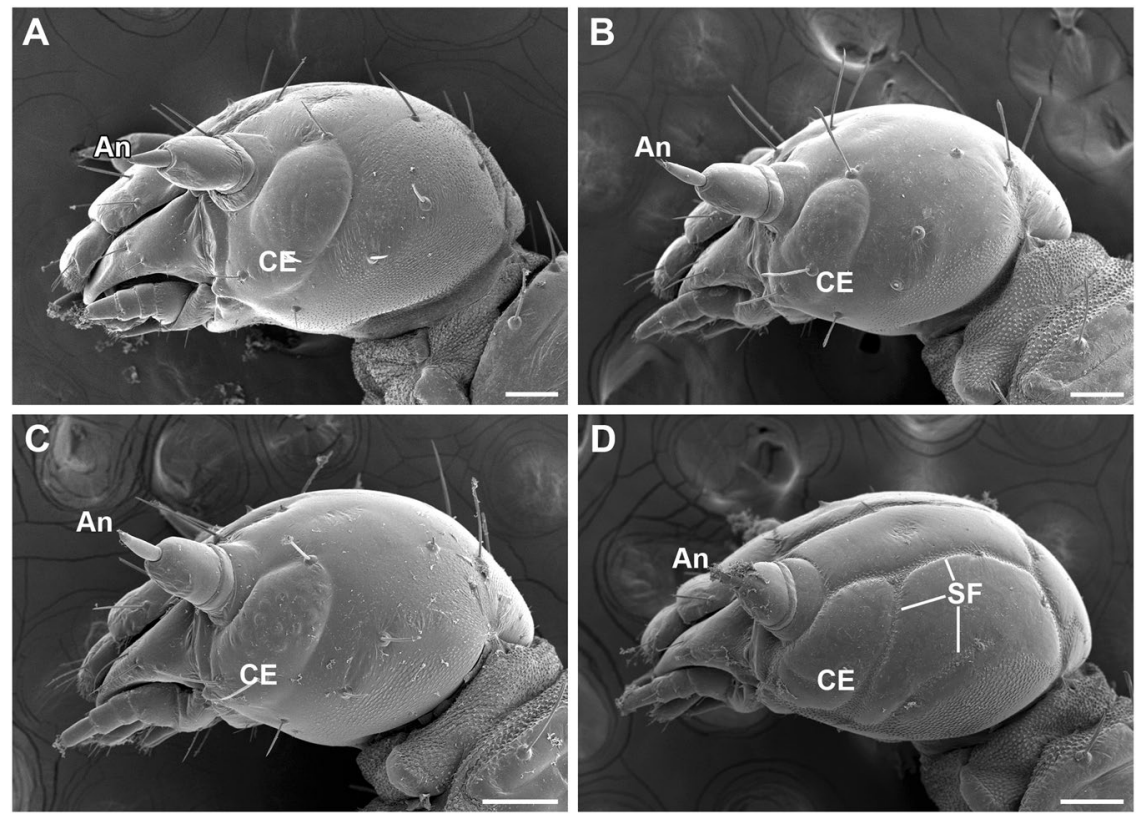

Figure 2. Larval heads of Panorpidae (lateral views). (A) Dicerapanorpa magna; (B) Cerapanorpa nanwutaina; (C) Panorpa curva; (D) Neopanorpa lipingensis. An, antenna; CE, compound eye; SF, shallow furrow. Scale bars $=100 \mu \mathrm{m}$.
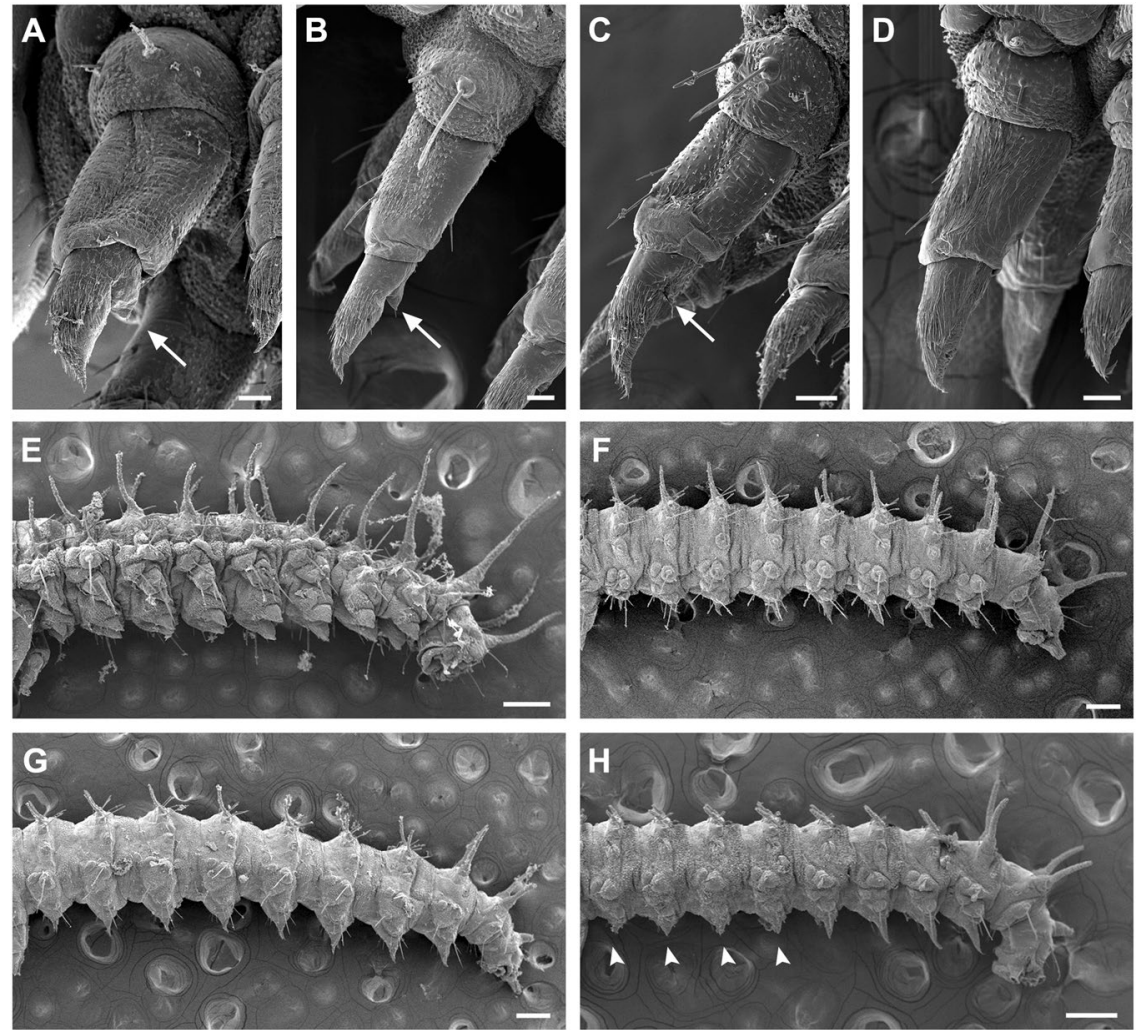

Figure 3. Larval thoracic legs and prolegs of Panorpidae. (A) and (E) Dicerapanorpa magna; (B) and (F) Cerapanorpa nanwutaina; (C) and (G) Panorpa curva; (D) and (H) Neopanorpa lipingensis; (A-D) prothoracic legs, arrows point to tibial lobes; $(\mathbf{E}-\mathbf{H})$ prolegs, arrow heads point to morphologically reduced prolegs on the anterior four abdominal segments. Scale bars: $(\mathbf{A}-\mathbf{D})=40 \mu \mathrm{m} ;(\mathbf{E})-(\mathbf{H})=200 \mu \mathrm{m}$.

In Cerapanorpa nearly half number of larvae stayed on the soil the whole day, with the number fluctuating slightly between 20 and 30 (Fig. 5C,D), also showing no distinct behavioral difference. 
Dicerapanorpa magna

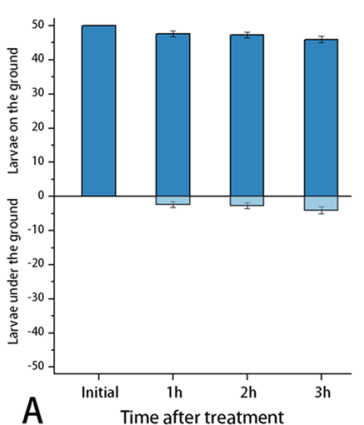

Dicerapanorpa sp

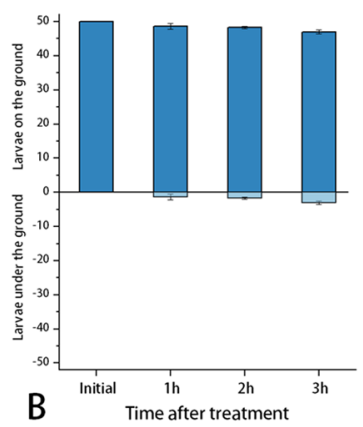

Cerapanorpa nanwutaina

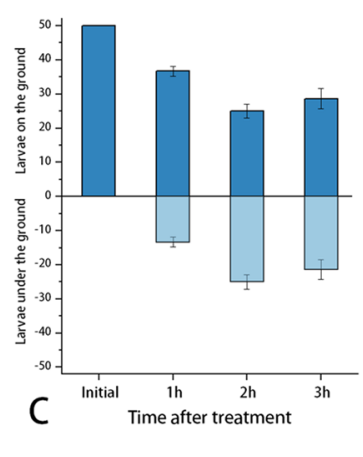

Cerapanorpa dubia

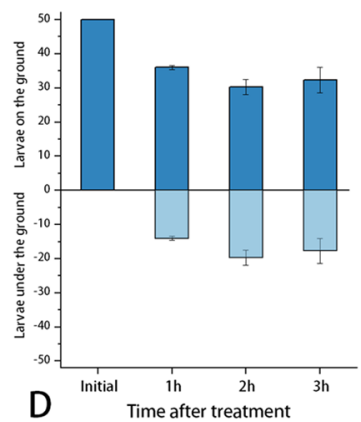

Panorpa curva

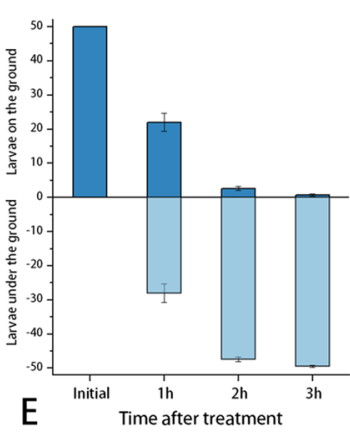

Panorpa chengi

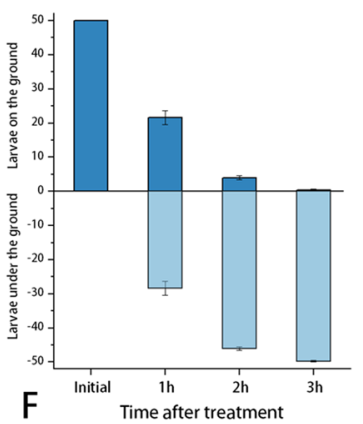

Neopanorpa lipingensis

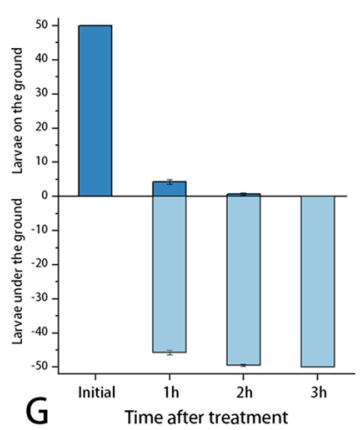

Neopanorpa longiprocess

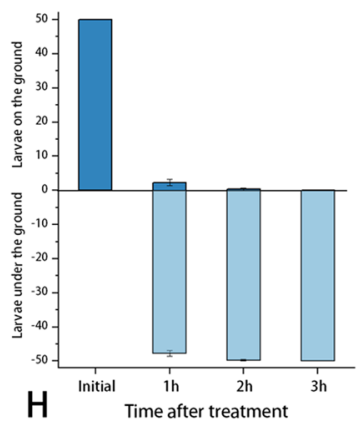

Figure 4. The number of larvae on/under the ground in three successive hours (Mean $\pm \mathrm{SEM}, n=3$ ), showing the habitat preference of larvae. (A) Dicerapanorpa magna; (B) Dicerapanorpa sp.; (C) Cerapanorpa nanwutaina; (D) Cerapanorpa dubia; (E) Panorpa curva; (F) Panorpa chengi; (G) Neopanorpa lipingensis; (H) Neopanorpa longiprocessa.

The larvae of Panorpa exhibited remarkable differences between the day and night because they were invisible during the day from 0800 to 1800 , but present on the soil surface after 2000 or 2200, before burrowing into the soil again when the sun rose at 0600 or 0800 (Fig. 5E,F). This indicates that the larvae of Panorpa are nocturnal, mainly active during the night.

In Neopanorpa the number of larvae on the soil fluctuated only slightly between the day and night. Approximately 10 of 50 larvae stayed on the soil at night from 2000 to 0600 , but very few of them were visible on the soil during the day from 0800 to 1800 (Fig. 5G,H). This further indicates that the larvae of Neopanorpa are euedaphic and nocturnal, most of which inhabit the soil during the day, and only comparatively active at night.

Molecular phylogeny and character evolution. Bayesian and maximum likelihood methods yielded phylogenetic trees of similar topologies in the combined three-gene analysis. Here, the consensus tree from the ML analysis was adopted to summarize the results (Fig. 6). All the four genera were confirmed to be monophyletic, with a high support value (posterior probability $=1$ ). Neopanorpa diverged from other genera the earliest in the panorpid species studied. Dicerapanorpa is the sister group to Cerapanorpa + Panorpa.

In general, morphological characters of larvae evolved congruently with the tree topology. The presence of shallow furrows on the larval head is definitely a synapomorphy supporting the monophyly of Neopanorpa. The longer antennae, presence of tibial lobe on thoracic legs, and proleg patterns strongly support the monophyly of Dicerapanorpa + (Cerapanorpa + Panorpa) (Fig. 6). On the contrary, the phenetic similarities with respect to body coloration are divergent from the tree topology. The darkened color of larval body is shared by the paraphyletic grade of Dicerapanorpa + Cerapanorpa. The pale color of body is shared by the assemblage of Neopanorpa + Panorpa (Fig. 6).

\section{Discussion}

Theoretically, the phenetic similarities could be considered as synapomorphies or homoplasy, depending on whether the species assemblage constitute a monophyletic group ${ }^{55}$. In this study, most anatomical characters of larvae are synapomorphies supporting the monophyly of Panorpidae. However, the phenetic similarities of body coloration are shared by paraphyletic assemblages, and are highly related to the specific habitats, implying the adaptive evolution of these edaphic larvae.

Edaphic arthropods can be further subdivided into epedaphic (living on the soil) and euedaphic (inhabiting the soil), and have evolved a range of morphological, physiological and behavioral characteristics that work in concert to permit survival in different microhabitats ${ }^{56}$. Epedaphic insects, like other exposed insects, need a variety of adaptive strategies, including efficient locomotive abilities ${ }^{57}$, well-developed visual organs ${ }^{58}$, and various kinds of protective body coloration ${ }^{59}$. Euedaphic insects, on the contrary, often bear fossorial legs or sclerotized mandibles for digging and burrowing in the substrate ${ }^{56,60}$, and smaller body size to pass unrestrictedly through 

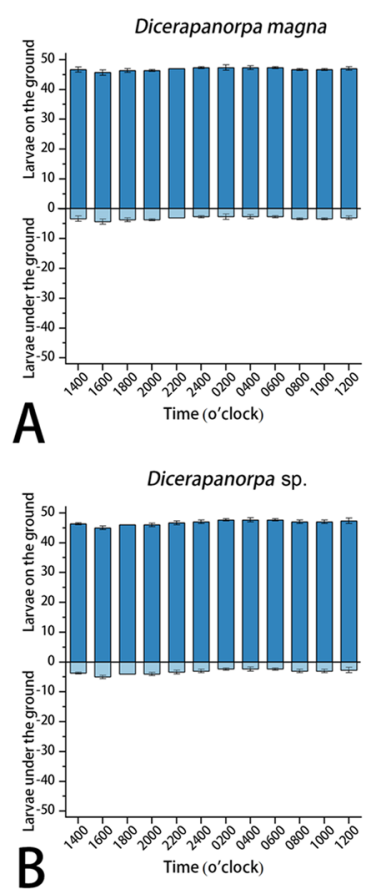
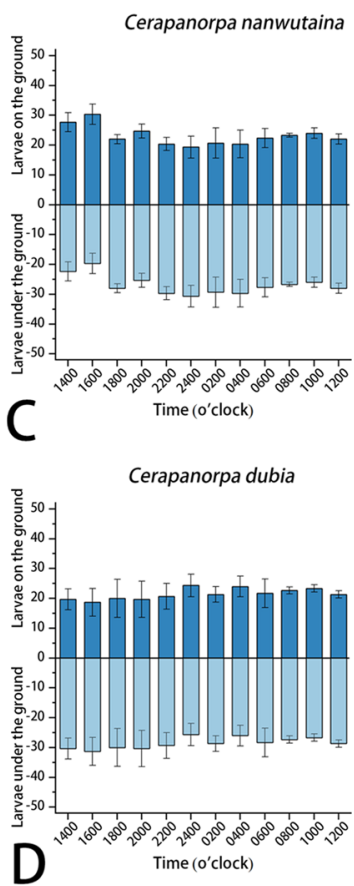
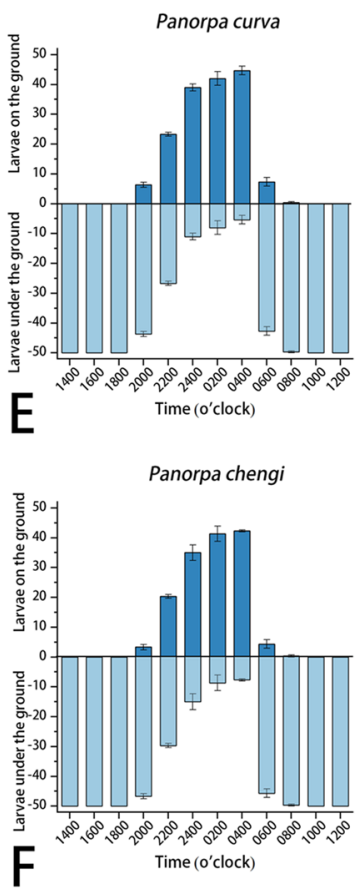
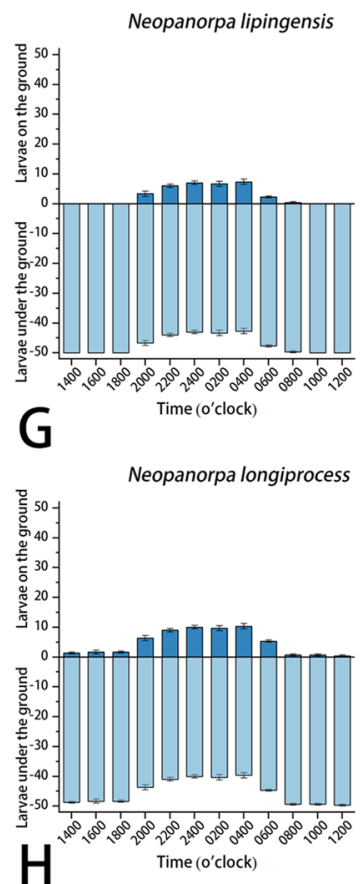

Figure 5. The number of larvae on/under the ground every two hours in a day (Mean \pm SEM, $n=3$ ), showing the circadian rhythm of larvae. (A) Dicerapanorpa magna; (B) Dicerapanorpa sp.; (C) Cerapanorpa nanwutaina; (D) Cerapanorpa dubia; (E) Panorpa curva; (F) Panorpa chengi; (G) Neopanorpa lipingensis; (H) Neopanorpa longiprocessa.

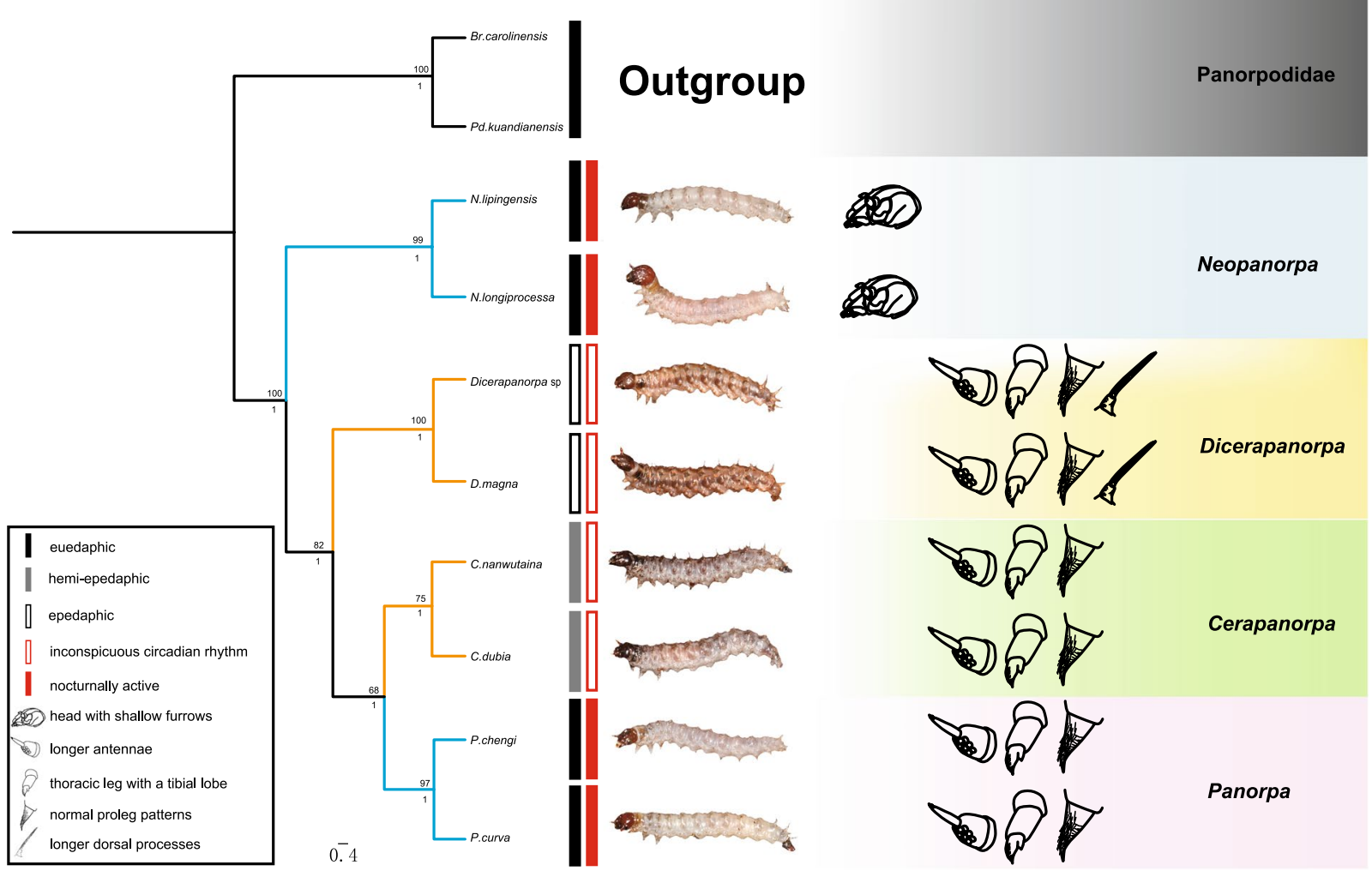

Figure 6. Maximum likelihood chronogram of the eight panorpid species inferred from the concatenated COI, COII and 28S. Node numbers above nodes show bootstrap values, numbers below node show posterior probability. The vertical bars in the middle depict the larval habits of species. The right markings show the morphological features of panorpid larvae. 
the pre-existing tunnels in the soils $\mathrm{s}^{61,62}$. Based on our present investigation, both epedaphic and euedaphic adaptive strategies were found in the larvae of Panorpidae.

The larvae of Dicerapanorpa are generally epedaphic, preferring to stay on the soil in the day and night. The larvae of Dicerapanorpa with a darkish dorsum have the color of soil for camouflage, as discussed in our previous study ${ }^{46}$. This strategy is also adopted by the ground-crawling larvae of Bittacidae, which spray soil on their body surface as camouflage ${ }^{48,63-65}$. Moreover, the larvae of Dicerapanorpa, Cerapanorpa, and Panorpa permanently or temporarily stay on the soil, all possessing well-developed thoracic legs with tibial lobes and well-developed abdominal prolegs (Fig. 6). These structures are likely to promote above-ground locomotive abilities and to support the larval abdomen during crawling on the soil ${ }^{66}$.

The larvae of Neopanorpa are exclusively euedaphic. These larvae prefer to stay in the soil all the time during the day and night. The euedaphic larvae of Neopanorpa all have shallow furrows on their head capsules ${ }^{41,67}$. The furrows help withstanding considerable mechanical pressure imposed on the head capsules during burrowing ${ }^{46}$. In addition, the antennae, cephalic setae, dorsal processes on the trunk, and four anterior pairs of prolegs are all shorter in the euedaphic larvae of Neopanorpa. These should facilitate their movement through the soil by decreasing friction and resistance ${ }^{61,62}$. It is worth noting further that the larval compound eyes of Neopanorpa are externally flat, and appears to be another adaptation to reduce friction.

With regard to habitat divergence, panorpid larvae are not only divided spatially, but also separated temporally. Nocturnal habit has evolved in the larvae of P. curva, P. chengi, N. lipingensis, and N. longiprocessa, similar to P. liui, $P$. virginica and $P$. lugubris, whose "above-ground searching" behaviors usually occur in the dark ${ }^{38,45,46}$. The nocturnal activity of these larvae likely reduces predation risk, as the night may offer safer foraging opportunities, i.e. protection from visually hunting predators ${ }^{68}$. Because they never expose to the light on the soil, it is unnecessary for the larvae of Panorpa and Neopanorpa to adopt camouflage strategies. As a result, these larvae are grossly pale, similar to soil-inhabiting white grubs of Scarabaeoidea ${ }^{69-71}$ and stem-boring weevils of Curculionidae in Coleoptera ${ }^{72}$.

Differing from herbivores or sexually mature insects, the saprophagous larvae of Panorpidae have no peculiar requirements for the co-evolution with specific host plants or heterosexual individuals ${ }^{10,12,19}$. The diversifying driving force of these edaphic saprophagous larvae probably attributes to the competition of habitat in the soil, which provide them organic matters as food ${ }^{31}$ and cavities as living space ${ }^{46}$. Owing to competition, the sympatric panorpid larvae that share a common ancestor switched to divergent ecological niches by subdividing the soil microhabitats on spatial and temporal aspects. In divergent niches, the larvae employ appropriate adaptive strategies that reflected diverse morphological features involving head capsules, setae, prolegs, and dorsal processes. On the other hand, the congeneric larvae occupying similar habitats share a common adaptive strategy and thus also morphological features. Consequently, our results would suggest that the habitat divergence has driven the morphological diversity, and may be partly responsible for the divergence of Panorpidae.

\section{References}

1. Condamine, F. L., Clapham, M. E. \& Kergoat, G. J. Global patterns of insect diversification: towards a reconciliation of fossil and molecular evidence? Sci. Rep. 6, 19208 (2016).

2. Grimaldi, D. \& Engel, M. S. Evolution of the Insects. (Cambridge University Press, Cambridge; 2005).

3. Ahrens, D., Schwarzer, J. \& Vogler, A. P. The evolution of scarab beetles tracks the sequential rise of angiosperms and mammals. Proc. R. Soc. B 281, 203-212 (2014).

4. Strong, D. R., Lawton, J. H. \& Southwood, T. R. E. Insects on Plants: Community Patterns and Mechanisms. (Harvard University Press, Cambridge, MA, 1984).

5. Farrell, B. D. \& Mitter, C. Adaptive radiation in insects and plants: time and opportunity. Am. Zool. 34, 57-69 (1994).

6. Farrell, B. D. "Inordinate Fondness" explained: Why are there so many beetles? Science 281 (1998).

7. Chen, R., Favret, C., Jiang, L. Y., Wang, Z. \& Qiao, G. X. An aphid lineage maintains a bark-feeding niche while switching to and diversifying on conifers. Cladistics 32, 555-572 (2015).

8. Buenaventura, E. \& Pape, T. Phylogeny of the Peckia-genus group: evolution of male genitalia in the major necrophagous guild of Neotropical flesh flies (Diptera: Sarcophagidae). Org. Divers. Evol. 15, 301-331 (2015).

9. Richmond, M. P., Park, J. \& Henry, C. S. The function and evolution of male and female genitalia in Phyllophaga Harris scarab beetles (Coleoptera: Scarabaeidae). J. Evol. Biol. 29, 2276-2288 (2016).

10. Hall, B. K. \& Wake, M. H. The Origin and Evolution of Larval Forms. (Academic Press, San Diego; 1999).

11. Schowalter, T. D. Insect Ecology: An Ecosystem Approach, Edn. 3rd edition. (Academic Press, San Diego; 2011).

12. Wagner, D. L. Caterpillars of Eastern North America: A Guide to Identification and Natural History. (Princeton University Press, Princeton, 2005).

13. Stehr, F. W. Immature Insects Vol. 1. (Kendall/Hunt Publishing Company, Dubuque, Iowa, 1987).

14. Foote, B. A. In Immature Insects, Vol. 2. (ed. Stehr, F. W.) 690-915 (Kendall/Hunt Publishing Company, Dubuque, Iowa; 1991).

15. Lawrence, J. F., Hastings, A. M., Dallwitz, M. J., Paine, T. A. \& Zurcher, E. J. Beetle Larvae of the World: Descriptions Illustrations, Identification and Information Retrieval for Families and Subfamilies. (CD-ROM, CSIRO Publ, Melbourne, 1999).

16. Newton, A. F. Larvae of Staphyliniformia (Coleoptera): where do we stand. Coleopt. Bull. 44, 205-210 (1990).

17. Byers, G.W. In Immature Insects, Vol. 1. (ed. Stehr, F. W.) 246-252 (Kendall/Hunt Publishing Company, Dubuque, Iowa, 1987).

18. Byers, G. W. In The Insects of Australia: A Textbook for Students and Research Workers, Vol. II, Edn. 2nd edition. (ed. CSIRO) 696-704 (Melbourne University Press, Carlton, 1991).

19. Byers, G. W. \& Thornhill, R. Biology of the Mecoptera. Annu. Rev. Entomol. 28, 203-228 (1983).

20. Byers, G.W. In Encyclopedia of Insects, Edn. 2nd edition. (eds Resh, V. H. \& Cardé, R. T.) 611-614 (Academic Press, San Diego; 2009).

21. Dunford, J. C. \& Somma, L. A. In Encyclopedia of Entomology. (ed. Capinera, J. L.) 3304-3310 (Springer, Heidelberg, Germany; 2008).

22. Willmann, R. The phylogenetic system of the Mecoptera. Syst. Entomol. 12, 519-524 (1987).

23. Beutel, R. G., Kristensen, N. P. \& Pohl, H. Resolving insect phylogeny: the significance of cephalic structures of the Nannomecoptera in understanding endopterygote relationships. Arthropod Struct. Dev. 38, 427-460 (2009).

24. Fraulob, M., Wipfler, B., Hünefeld, F., Pohl, H. \& Beutel, R. G. The larval abdomen of the enigmatic Nannochoristidae (Mecoptera, Insecta). Arthropod Struct. Dev. 41, 187-198 (2012).

25. Pilgrim, R. L. C. The aquatic larva and the pupa of Choristella philpotti Tillyard, 1917 (Mecoptera: Nannochoristidae). Pac. Insects 14, 151-168 (1972).

26. Cooper, K. W. Sexual biology, chromosomes, development, life histories and parasites of Boreus, especially of B. notoperates. A southern California Boreus. II. (Mecoptera: Boreidae). Psyche 81, 84-120 (1974). 
27. Russell, L. K. The life history of Caurinus dectes Russell, with a description of the immature stages (Mecoptera: Boreidae). Entomol. Scand. 13, 225-235 (1982).

28. Fabian, B., Russell, L., Friedrich, F. \& Beutel, R. G. The larval cephalic morphology of the enigmatic boreid Caurinus dectes (Mecoptera) and its phylogenetic significance. Arthropod Syst. Phyl. 73, 385-399 (2015).

29. Byers, G. W. Biology of Brachypanorpa (Mecoptera: Panorpodidae). J. Kansas Entomol. Soc. 70, 313-322 (1997).

30. Jiang, L., Yue, C. \& Hua, B. Z. Larval morphology of Panorpodes kuandianensis (Insecta, Mecoptera, Panorpodidae) and its evolutionary implications. ZooKeys 398, 69-82 (2014).

31. Jiang, L. \& Hua, B. Z. Functional morphology of the larval mouthparts of Panorpodidae compared with Bittacidae and Panorpidae (Insecta: Mecoptera). Org. Divers. Evol. 15, 671-679 (2015).

32. Gao, C., Ma, N. \& Hua, B. Z. Cerapanorpa, a new genus of Panorpidae (Insecta: Mecoptera) with descriptions of three new species. Zootaxa 4158, 93-104 (2016).

33. Hu, G. L., Yan, G., Xu, H. \& Hua, B. Z. Molecular phylogeny of Panorpidae (Insecta: Mecoptera) based on mitochondrial and nuclear genes. Mol. Phylogenet. Evol. 85, 22-31 (2015).

34. Zhong, W. \& Hua, B. Z. Dicerapanorpa, a new genus of East Asian Panorpidae (Insecta: Mecoptera: Penorpidae) with descriptions of two new species. J. Nat. Hist. 47, 1019-1046 (2013).

35. Wang, J. S. \& Hua, B. Z. An annotated checklist of the Chinese Mecoptera with description of male Panorpa guttata Navás, 1908. Entomotaxonomia 39, 24-42 (2017).

36. Wang, J. S. \& Hua, B. Z. Megapanorpa, a new genus with a single anal horn in males from Oriental China (Mecoptera: Panorpidae). Entomol. Sci. 22, 64-79 (2019).

37. Miao, Y., Wang, J. S. \& Hua, B. Z. Molecular phylogeny of the scorpionflies Panorpidae (Insecta: Mecoptera) and chromosomal evolution. Cladistics 35, 385-400 (2019).

38. Mampe, C. D. \& Neunzig, H. H. Larval descriptions of two species of Panorpa (Mecoptera: Panorpidae), with notes on their biology. Ann. Entomol. Soc. Am. 58, 843-849 (1965).

39. Miyaké, T. The life-history of Panorpa klugi M’Lachlan. J. Coll. Agric. Imp. Univ. Tokyo 4, 117-139 (1912).

40. Steiner, P. Studien an Panorpa communis L. Z. Morphol. Ökol. Tiere 17, 1-67 (1930).

41. Yie, S. T. The biology of Formosan Panorpidae and morphology of eleven species of their immature stages. Mem. Coll. Agric. Natl. Taiwan Univ. 2, 1-111 (1951).

42. Boese, A. E. Descriptions of larvae and key to fourth instars of North American Panorpa (Mecoptera: Panorpidae). Univ. Kansas Sci. Bull. 50, 163-186 (1973).

43. Brauer, F. B. zur Kenntniss der Panorpiden-Larven. Verh. Zool-Bot. Ges. 13, 307-324 (1863).

44. Chen, H. M. \& Hua, B. Z. Morphology and chaetotaxy of the first instar larva of the scorpionfly Sinopanorpa tincta (Mecoptera: Panorpidae). Zootaxa 2897, 18-26 (2011).

45. Jiang, L. \& Hua, B. Z. Morphology and chaetotaxy of the immature stages of the scorpionfly Panorpa liui Hua (Mecoptera: Panorpidae) with notes on its biology. J. Nat. Hist. 47, 2691-2705 (2013).

46. Jiang, L. \& Hua, B. Z. Morphological comparison of the larvae of Panorpa obtusa Cheng and Neopanorpa lui Chou \& Ran (Mecoptera: Panorpidae). Zool. Anz. 255, 62-70 (2015).

47. Ma, N., Chen, H. M. \& Hua, B. Z. Larval morphology of the scorpionfly Dicerapanorpa magna (Chou) (Mecoptera: Panorpidae) and its adaptive significance. Zool. Anz. 253, 216-224 (2014).

48. Jiang, L., Gao, Q. H. \& Hua, B. Z. Larval morphology of the hanging-fly Bittacus trapezoideus Huang \& Hua (Insecta: Mecoptera: Bittacidae). Zootaxa 3957, 324-333 (2015).

49. Whiting, M. F. Phylogeny of the holometabolous insect orders: molecular evidence. Zool. Scr. 31, 3-15 (2002).

50. Pollmann, C., Misof, B. \& Sauer, K. P. Molecular phylogeny of panorpodid scorpionflies: An enigmatic, species-poor family of Mecoptera (Insecta). Org. Divers. Evol. 8, 77-83 (2008).

51. Swindell, S. R. \& Plasterer, T. N. SEQMAN. Contig assembly. Methods Mol. Biol. 70, 75-89 (1997).

52. Jeanmougin, F., Thompson, J. D., Gouy, M., Higgins, D. G. \& Gibson, T. J. Multiple sequence alignment with Clustal X. Trends Biochem. Sci. 23, 403-405 (1998).

53. Hall, T. A. BioEdit: a user-friendly biological sequence alignment editor and analysis program for Windows 95/98/NT. Nucleic Acids Symp. Ser. 41, 95-98 (1999).

54. Lanfear, R., Calcott, B., Ho, S. Y. W. \& Guindon, S. PartitionFinder: combined selection of partitioning schemes and substitution models for phylogenetic analyses. Mol. Biol. Evol. 29, 1695-1701 (2012).

55. Wiley, E. O. \& Lieberman, B. S. Phylogenetics: Theory and Practice of Phylogenetic Systematics, Edn. 2nd edition. (John Wiley \& Sons, Inc., Hoboken, New Jersey, 2011).

56. Villani, M. G., Allee, L. L., Díaz, A. \& Robbins, P. S. Adaptive strategies of edaphic arthropods. Annu. Rev. Entomol. 44, 233-256 (1999).

57. Delcomyn, F. In Locomotion and Energetics in Arthropods. (eds Herreid, C. F. \& Fourtner, C. R.) 105-125 (Plenum, New York, 1981).

58. Gilbert, C. Form and function of stemmata in larvae of holometabolous insects. Annu. Rev. Entomol. 39, 323-349 (1994).

59. Ruxton, G. D., Sherratt, T. N. \& Speed, M. P. Avoiding Attack: The Evolutionary Ecology of Crypsis, Warning Signals and Mimicry. (Oxford University Press, Oxford, 2005).

60. Bai, M. et al. Mandible evolution in the Scarabaeinae (Coleoptera: Scarabaeidae) and adaptations to coprophagous habits. Front. Zool. 12, 30 (2015).

61. Dindal, D. L. Soil Biology Guide. (Wiley, New York, 1990).

62. Eisenbeis, G. \& Wichard, W. Atlas on the Biology of Soil Arthropods. (Springer-Verlag, Berlin, 1987).

63. Setty, L. R. Biology and morphology of some North American Bittacidae (Order Mecoptera). Am. Midl. Nat. 23, 257-353 (1940).

64. Liu, L. \& Hua, B. Z. Ultrastructure of the larval midgut of Bittacus planus (Mecoptera: Bittacidae) and Neopanorpa longiprocessa (Mecoptera: Panorpidae). Tissue \& Cell 49, 622-631 (2017).

65. Liu, L \& Hua, B. Z. Ultrastructure of the rectum of the soil-spraying larva in Bittacus cirratus (Mecoptera: Bittacidae). Protoplasma, https://doi.org/10.1007/s00709-019-01394-y (2019).

66. Yue, C. \& Hua, B. Z. Are abdominal prolegs serially homologous with the thoracic legs in Panorpidae (Insecta: Mecoptera)? Embryological evidence. J. Morphol. 271, 1366-1373 (2010).

67. Cai, L. J. \& Hua, B. Z. A new Neopanorpa (Mecoptera: Panorpidae) from China with notes on its biology. Dtsche. Entomol. Z. 56, 93-99 (2009).

68. Kronfeld-Schor, N. \& Dayan, T. Partitioning of time and ecological resource. Annu. Rev. Ecol. Evol. Syst. 34, 153-181 (2003).

69. Ritcher, P. O. White Grubs and Their Allies: A Study of North American Scarabaeoid Larvae. (Oregon State University Press, Corvallis, Oregon, 1966).

70. Fang, H., Li, C. \& Jiang, L. Morphology of the immature stages of Adoretus tenuimaculatus Waterhouse, 1875 (Coleoptera: Scarabaeidae: Rutelinae: Adoretini). J. Asia Pac. Entomol. 21, 1159-1164 (2018).

71. Li, C., Lu, Y., Fang, H. \& Jiang, L. Morphology of the third instar larva of Colobopterus quadratus (Coleoptera: Scarabaeidae: Aphodiinae) using scanning electron microscopy. Microsc. Res. Tech. 82, 1372-1379 (2019).

72. Gosik, R. \& Wanat, M. Descriptions of immature stages of the weevil Lixus punctiventris Boheman, 1835 (Coleoptera, Curculionidae, Lixini). Zootaxa 3754, 159-172 (2014). 


\section{Acknowledgements}

We thank Jie Lu and Lu Liu for assistance in rearing the larvae. We also thank Ying Miao and Wen Zhong for kindly identifying some specimens. Our special thanks go to Kees van Achterberg and Victor Benno MayerRochow for valuable comments and linguistic supports for the manuscript. We are grateful to two anonymous reviewers for their valuable comments. This research was funded by the National Natural Science Foundation of China (Grant nos. 31872278, 31672341, and 31372186) and the Specialized Research Fund for the Doctoral Program of Higher Education of China (Grant no. 20130204130001). This research was also supported by the Open Project of the Key Laboratory of Plant Protection Resources and Pest Management of Ministry of Education of China. (Grant no. A115020002-2017-02).

\section{Author Contributions}

Conceived and designed the experiments: L.J., Y.H. Performed the experiments: L.J. Analyzed the data: L.J., Y.H., G.L.H. Wrote the paper: L.J., Y.H., G.L.H., B.Z.H.

\section{Additional Information}

Supplementary information accompanies this paper at https://doi.org/10.1038/s41598-019-49211-z.

Competing Interests: The authors declare no competing interests.

Publisher's note: Springer Nature remains neutral with regard to jurisdictional claims in published maps and institutional affiliations.

(c) Open Access This article is licensed under a Creative Commons Attribution 4.0 International License, which permits use, sharing, adaptation, distribution and reproduction in any medium or format, as long as you give appropriate credit to the original author(s) and the source, provide a link to the Creative Commons license, and indicate if changes were made. The images or other third party material in this article are included in the article's Creative Commons license, unless indicated otherwise in a credit line to the material. If material is not included in the article's Creative Commons license and your intended use is not permitted by statutory regulation or exceeds the permitted use, you will need to obtain permission directly from the copyright holder. To view a copy of this license, visit http://creativecommons.org/licenses/by/4.0/.

(C) The Author(s) 2019 